\title{
BO74 CHARACTERIZATION OF THE MANGANESE SITES IN MANGANESE REDOX ENZYMES: CATALASE AND SUPEROXIDE DISMUTASE.
}

T. Stemmlera, D. Tierney ${ }^{\mathrm{a}}$, G.Waldo ${ }^{\mathrm{a}}$, M. Lahb, M. Ludwigb, Le Penner-Hahn a Department of Chemistry and ${ }^{a}$ Biophysics Research Division, The University of Michigan, Ann Arbor, Michigan, 48109-1055, USA

Mn plays a key role in a variety of redox proteins, including superoxide dismutase (mononuclear Mn site), catalase (dinuclear $\mathrm{Mn}$ site) and the photosynthetic oxygen evolving complex (tetranuclear Mn site). Recent work on the structural, kinetic, and spectroscopic characterization of the Mn sites in the catalase and in $\mathrm{Mn}$ and $\mathrm{Fe}$ superoxide dismutase will be described.

For Mn catalase, a combination of activity measurements, EPR and x-ray absorption spectroscopy $[1,2]$ has lead to the kinetic model shown in Fig. 1,

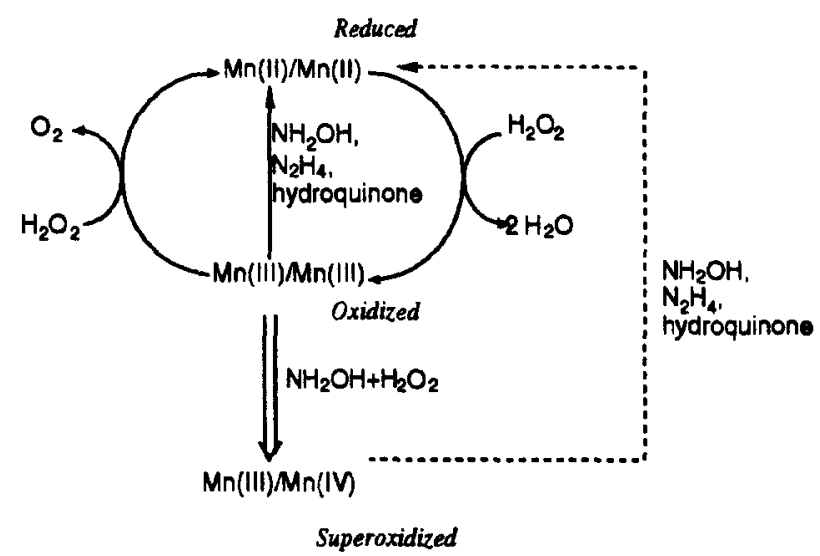

Figure 1. Oxidation state interconversions of Mn catalase. with the active enzyme cycling between $\mathrm{Mn}$ II $/ \mathrm{Mn}^{\mathrm{II}}$ and $\mathrm{Mn}^{\mathrm{III}} / \mathrm{Mn}^{\mathrm{III}}$ oxidation states. An inactive, superoxidized $\mathrm{Mn}^{\mathrm{II}} / \mathrm{Mn}^{\mathrm{IV}}$ derivative can be prepared by $\mathrm{NH}_{2} \mathrm{OH}+\mathrm{H}_{2} \mathrm{O}_{2}$ treatment. This inactive derivative has is structurally [2] and spectroscopically [3] similar to the active $S_{2}$ state of the photosynthetic oxygen evolving complex. Azide is a competitive inhibitor of Mn catalase and NMR data suggest that azide binds to the $\mathrm{Mn}^{\mathrm{II}} \mathrm{Mn}$ II enzyme with

displacement of a bound water. Azide binding to the $\mathrm{Mn}^{\mathrm{III}} / \mathrm{Mn}^{\mathrm{IV}}$ derivative causes only minor perturbations to its EPR spectrum.

The $\mathrm{Mn}$ and $\mathrm{Fe}$ superoxide dismutases are highly homologous proteins, with very similar metal binding sites ( 3 His +1 Asp + (possibly) 1 water). EXAFS and XANES data [4] for the native ferric enzyme show a 5 five coordinate metal site (i.e., confirm the presence of a coordinated solvent molecule) Data for the native+azide and the high-pH forms of the enzyme show that here the metal site is six coordinate, demonstrating that these anions bind without displacement of the solvent molecule.

1. G.S. Waldo, R.M. Fronko, \& J.E. Penner-Hahn, Biochemistry, 3010486 (1991) .

2. G.S. Waldo, S. Yu and J.E. Penner-Hahn, J. Am. Chem. Soc., 114, 5869 (1992)

3. A. Haddy, G.S. Waldo, R. Sands, and J.E. Penner-Hahn, J. Am. Chem. Soc., submitted.

4. D. Tierney, M.S. Lah, M. Ludwig, J.E. Penner-Hahn, manuscript in preparation. 